\title{
Issues and Challenges in Using Zakat for The Development of Micro Takaful
}

Nik Abdul Rahim Nik Abdul Ghani, Ihsan Ilahi Mohd Sabri, Azlin Alisa Ahmad

To Link this Article: http://dx.doi.org/10.6007/IJARBSS/v11-i4/9661

DOI:10.6007/IJARBSS/v11-i4/9661

Received: 01 February 2021, Revised: 02 March 2021, Accepted: 25 March 2021

Published Online: 15 April 2021

In-Text Citation: (Ghani et al., 2021)

To Cite this Article: Ghani, N. A. R. N. A., Sabri, I. I. M., \& Ahmad, A. A. (2021). Issues and Challenges in Using Zakat for The Development of Micro Takaful. International Journal of Academic Research in Business and Social Sciences, 11(4), 217-229.

\section{Copyright: (c) 2021 The Author(s)}

Published by Human Resource Management Academic Research Society (www.hrmars.com)

This article is published under the Creative Commons Attribution (CC BY 4.0) license. Anyone may reproduce, distribute, translate and create derivative works of this article (for both commercial and non-commercial purposes), subject to full attribution to the original publication and authors. The full terms of this license may be seen

at: http://creativecommons.org/licences/by/4.0/legalcode

Vol. 11, No. 4, 2021, Pg. 217 - 229

Full Terms \& Conditions of access and use can be found at http://hrmars.com/index.php/pages/detail/publication-ethics 


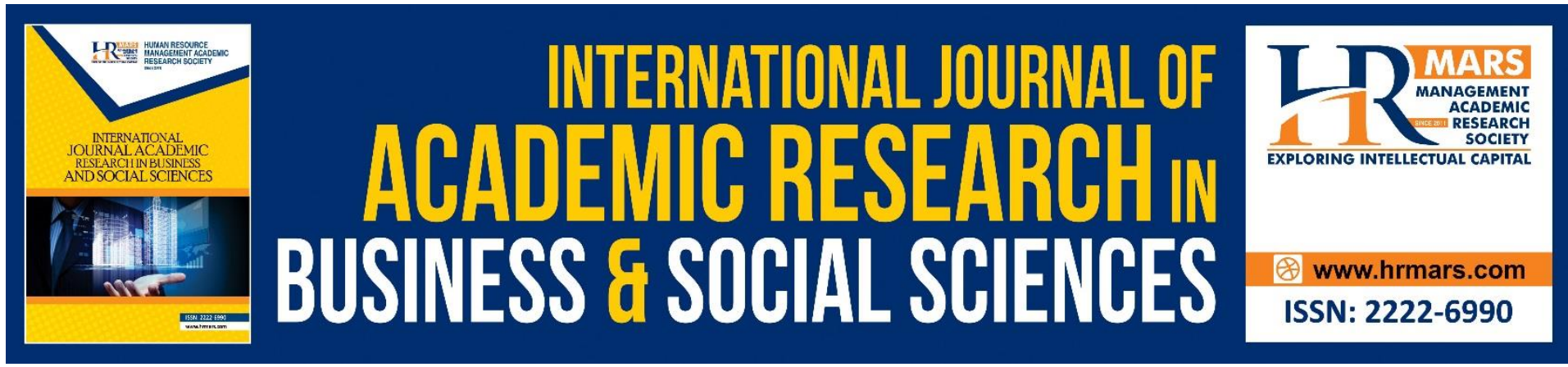

\title{
Issues and Challenges in Using Zakat for The Development of Micro Takaful
}

\author{
Nik Abdul Rahim Nik Abdul Ghani, Ihsan Ilahi Mohd Sabri, Azlin \\ Alisa Ahmad.
}

Research Centre for Sharia, Faculty of Islamic Studies, Universiti Kebangsaan Malaysia

Email: azlinalisa@ukm.edu.my

\begin{abstract}
Micro Takaful is an affordable takaful that targets the poor in efforts to help them obtain protection for themselves and their family. The National Bank of Malaysia or Bank Negara Malaysia (BNM), encourages the takaful industry to provide micro takaful products for the targeted group. However, micro takaful is still at a minimum because the poor cannot consistently pay their monthly contributions due to financial difficulties. This study intended to explain the issues and challenges of using zakat as a micro takaful development fund. This qualitative study used the interview method comprising semi-structured questions for collecting data from three institutions, namely Syarikat Takaful Malaysia Keluarga Berhad, Mufti's Office, Federal Territory Islamic Religious Council and Mufti's Office, Selangor Islamic Religious Council. Findings show that there are two categories of issues and challenges, namely from the Islamic law aspect and the implementation of zakat as a source of fund for micro takaful.
\end{abstract}

Keywords: Micro Takaful, Zakat, Issues, Challenges

\section{Introduction}

Micro takaful is an affordable protection plan that targets the low-income household group as well as small businesses. Micro Takaful was formed in Malaysia in 2007, beginning with the collaboration between Syarikat Takaful Ikhlas and the Farmers' Association of Malaysia, whereby contributions for the micro takaful plan fully subsidised by the government, which targeted 100,000 farmers at one time (Mamdouh, 2016). In 2010, BNM had urged the takaful industry to introduce a micro takaful product that targeted the poor (Wahid \& Noordin, 2014).

However, there a very low percentage of the poor held takaful policies (Abdul Wahid \& Noordin, 2014; Salleh \& Padzim, 2018), with only 4\% of low income households holding a takaful policy (BNM, 2016). Hence, studies had suggested the use of zakat funds (Mamdouh, 2016; Nik Abdul Ghani et al., 2018; Mohd Rom \& Abdul Rahman, 2012; Mikail \& Ahmad, 2017) and wakaf (Mikail \& Ahmad, 2017) for helping the poor to own takaful policies as a form of protection for themselves and their families.

Nevertheless, there were still several issues and challenges that needed to be overcome, mainly related to zakat funds that involved Islamic law and its use as a micro takaful development fund because zakat is bound by specific divine texts (nas), specifically 
the al-Quran and hadith as well as the Malaysian constitution. Hence, this study analyses the issues and challenges of integrating zakat for developing micro takaful in order to reduce the percentage of risk faced by the low-income household. This study begins with the discussions on the micro takaful concept and micro takaful products in Malaysia. The study then explores issues and challenges of using zakat funds as a fund for developing micro takaful. The discussion is divided into two parts, i.e., i) issues and challenges related to Islamic law and ii) issues and challenges related to the implementation and procedures.

\section{The Micro Takaful Concept}

'Takaful' originates from the Arabic word kafala, which means mutual guarantee. According to Section 3 of the Islamic Financial Services Act 2013, takaful is an arrangement based on mutual assistance under which takaful participants agree to contribute to a common fund providing for mutual financial benefits payable to the takaful participants or their beneficiaries on the occurrence of pre-agreed events (Islamic Financial Services Act, 2013).

Takaful also refers to a consensus between at least two parties who agree to mutually guarantee one another if there is a liability caused by a natural calamity or disaster (Zulkifli et al., 2012). This definition means that a group of individuals agree to guarantee one another in the case of any loss or risk befalls any one of them. Takaful is built on several noble concepts that are morally encouraged and ordered in Shariah, such as the concept of mutual protection, assistance and solidarity between participants who had agreed to share the underlined losses or risks, which are paid for by the takaful fund (Engku Ali, 2010).

Micro literally means small (Hornby n.d.). Combining the words 'micro' and 'takaful' leads to the word 'micro takaful', which is defined as a takaful product specially created to provide financial protection to the low-income household (BNM, 2016). Micro takaful acts as an alternative that allows the poor to own a takaful policy, which provided protection that is Shariah-compliant and specifically designed for the unfortunate, such as the poor, with an affordable price (Abdul Wahid \& Noordin, 2014; Puad, 2017). Briefly, a product is presumed to be micro takaful when it fulfils three criteria, namely being Shariah-compliant, specifically for those who cannot afford a standard takaful product and the price offered is reasonable and affordable.

The intention of forming the micro takaful scheme is to achieve several objectives. One is to reduce poverty and help the low-income group to obtain takaful protection for finances and future protection of lives (BNM, 2016; Salleh \& Padzim, 2018). According to Raffie (2018), there are three objectives of micro takaful, which are based on the parties involved.

\section{i. Government and Policy Maker}

Micro takaful is one way of ensuring inclusive growth and support for the part of society that is exposed to risks.

\section{ii. Social organisation and development}

Micro takaful can be a tool for reducing the level of poverty. 


\section{iii. Takaful operators and others}

Provides an opportunity for exploring new segments of the market as well as support market growth and takaful.

Based on the guidelines stipulated by BNM in the Discussion Paper on Microinsurance and Microtakaful, a microtakaful product should demonstrate the following principles (BNM, 2016)

\section{i. Simple}

A takaful product must be easy to understand, beneficial and its conditions must be clearly and concisely stated.

\section{ii. Protection needs-driven}

The risk protection offered must be suitable with the targeted group, who are the poor. Likewise, any sort of unsuitable protection plan should not be offered.

\section{iii. Accessible}

Takaful's premium should be affordable and suitable based on the current situation of the target group. Processes, such as monthly premium payments, benefit claims, and renewal of takaful certificates, must be simplified and convenient according to the policies of the takaful company

\section{iv. Efficient}

All processes should be ideally carried out is an organised, efficient and time saving manner. Based on these three principles, it can be concluded that micro takaful is a takaful specifically meant for the incapacitated group, lowly priced as well as the application and claim processes made simpler minus the strict and inconvenient conditions.

Besides that, Mamdouh (2016) stresses on some characteristics of micro takaful that differentiate it from other normal takaful, which are described below:

\section{i. Micro Takaful based on the principle of brotherhood and unity}

The basis for micro takaful is welfare and not profit. Hence, a takaful company must understand this concept so that micro takaful can be widely marketed with the objective of helping the poor.

\section{ii. Micro takaful needs an enormous risk savings fund}

The micro takaful contribution rate is minimal and specially formulated so that it is affordable, especially by the poor. Therefore, the risk fund must be big in order to cater for the expenses accrued when providing benefits in the case of any risk.

In Malaysia, micro takaful is still in its infancy stage as compared to other countries (Raffie, 2019). This is because the income earned by the poor is unstable or not fixed, which makes it difficult for them to contribute on a monthly basis. Moreover, the daily income is spent on necessities such as food etc. and if there any remainder, only then can it be spent on other items such as micro takaful. This is the reason for the suggestion to use zakat funds as a source of micro takaful contributions for the poor. 


\section{MICRO TAKAFUL PRODUCTS IN MALAYSIA}

Micro takaful has been implemented in several countries, such as Indonesia, Lebanon, Sri Lanka and Bangladesh (Mamdouh, 2016). There are several micro takaful products offered in Malaysia in efforts to help the low-income group, some of which are mentioned below.

\section{a. MySalam}

MySalam is a protection scheme specifically aimed at providing protection for the B40 and is wholly borne by the government. MySalam is given to those who receive the 'cost of living assistance' (BSH) from the government and those aged between 18 and 55 years (MySalam Official Portal, 2020). My Salam is also a free takaful plan for BSH recipients who are suffering from one of the 36 critically listed diseases. Among the assistance provided is RM 8000 in cash when someone is certified as suffering from one of the 36 critical diseases ascertained by the Health Ministry. RM50 to RM700 for government hospital treatment charges involving certain hospitals determined by the government. MySalam is managed by Great Eastern Takaful Berhad, which is a takaful company listed under the Islamic Financial Act 2013, and is placed under the supervision of BNM.

\section{b. Tenang Protection Plan}

Bank Negara Malaysia (BNM) has launched an affordable protection model called Tenang Protection. At the end of 2017, there were 10 Tenang Protection products issued by 10 companies consisting of six life insurance companies, three family takaful companies and one general insurance company (BNM, 2017). Among these companies are the Malaysian Takaful Association, General Insurance Association of Malaysia (PIAM) and the Life Insurance Association of Malaysia (PIHM). On 24 November 2017, BNM launched a Tenang Protection product with the aim of widening the function or role of insurance or takaful in efforts to help the poor, especially the B-40 (Chiew, 2017). Tenang Protection is recognisable by its logo, which is easy to read and understand.

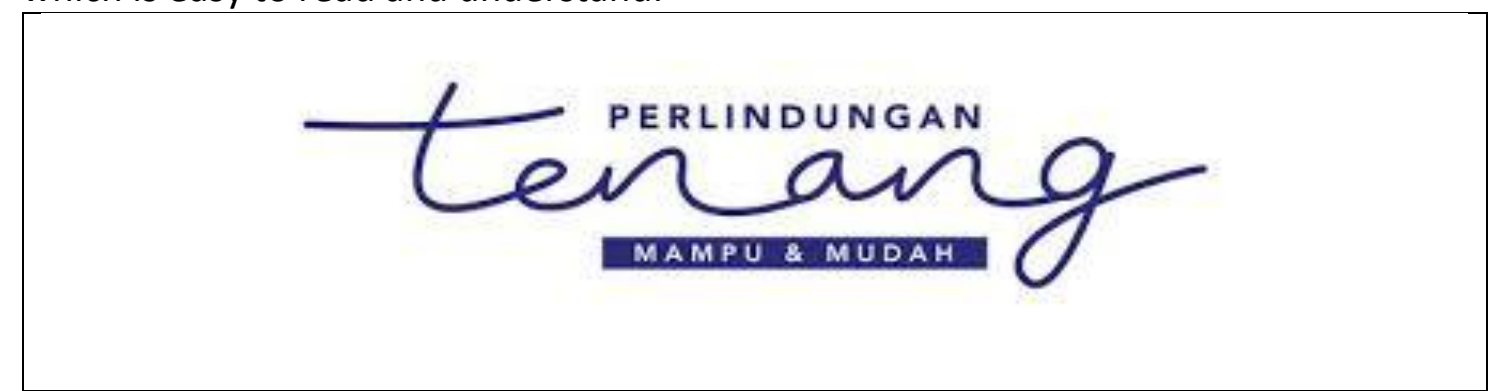

Diagram 2.1: The Tenang Protection Logo (Bank Negara Malaysia 2017).

According to Chiew (2017), the Tenang Protection product must adhere to several guidelines stipulated by BNM, some of which are mentioned below.

\section{i. Affordability}

The established monthly contributions must be affordable. The premium rates must be evaluated from various aspects, such as income, employment, number of household members, availability of emergency savings and social security networks. Therefore, BNM had established that monthly premium rates should not exceed RM15. The low premium rate of RM15 can help the B40 group to own takaful as a form of protection plan for them. 


\section{ii. Good Value}

In order to ensure that the Tenang protection product offers good value to the B40 group, the operator must cover the most important risk associated with a household as well as maximise the premium paid to provide protection benefits. Normally, agencies or companies do not provide appropriate premium rates as stipulated in the Tenang Protection product. To enable this, agencies need to think of an innovation in the distribution model in order to optimise costs. This requires a study on the decision to invest, including investment opportunities in the market in order to avoid critical risky investment opportunities.

\section{iii. Accessibility}

Protection under the Tenang Protection product and benefits of the protection must be determined clearly based on certain situations, such as location, employment or type of living quarters that are usually related to the B40 group. Product and services must be provided in easily accessible locations, such as hospitals, towns, Urban Transformation Centres (UTC/RTC) and sundry shops. Advertising these products on the internet is an option because B40s usually lack internet facilities in their homes.

\section{iv. Easy to Understand}

All information in the Tenang Protection product, such as benefits, terms and product conditions, must be designed to facilitate the user to clearly understand what is insured and conditions of the takaful plan. Company operators should reduce items that are not required in their products, which are somethings difficult for the B40 to understand. Product marketing should include clear and easily comprehensible information to help users make accurate decisions for identifying suitable and affordable protection plans for them

\section{v. Easy to Purchase and Make Claims}

Besides being easy to purchase, the claim process must also be easy and convenient. The requirement for supporting documents when making claims should be clearly stated. BNM has stipulated that claim payments must be made within five working days from the date of adducing the complete set of documents. Several innovations have been introduced to encourage the B40 to participate in the Tenang Protection product, such as family takaful products that provide benefits to the beneficiary after the demise of the policy holder with claims easily processed after receiving pertinent documents through social media (WhatsApp), receipt of documents certified by the village head, headmaster or police officer and products related to burial benefits that will be paid within 24 hours by using the burial permit as an alternative to the death certificate (BNM, 2017). All these innovations are intended to help the B40 group to face risks, such as death, sickness etc.

Since the launch, the progress on Perlindungan Tenang has been encouraging, with a total of 13 licensed insurers and licensed takaful operators offering microinsurance and microtakaful products through various distribution channels which have provided protection coverage to nearly 75 thousand people as at end-2019. As such, for further development, Bank Negara Malaysia is reviewing the Perlindungan Tenang framework to drive greater innovation and diversity in products offerings to better cater to the needs of the unserved and underserved segments (BNM, 2020). 


\section{c. I-BR1M}

According to the details of the Takaful Ikhlas (2020) product sheet, i-BR1M is a takaful plan that provides benefits to BR1M recipients, either in the household or family categories. The government's aim of forming i-BR1M is to help alleviate the burden of BR1M family fund recipients in the case of a death or permanent loss of ability due to an accident. All BR1M recipients are eligible to apply for $\mathrm{i}-\mathrm{BR} 1 \mathrm{M}$, except single individuals or single senior citizens. Among the benefits provided by $\mathrm{i}-\mathrm{BR} 1 \mathrm{M}$ are an assistance of RM1000 in the case of death not caused by an accident, an assistance of RM 30000 for death caused by an accident, an assistance of RM30000 if there is a total permanent loss of ability caused by an accident. The i-BR1M fund is fully subsidised by the Malaysian government and managed by Takaful Ikhlas Malaysia Sdn. Bhd, hence, participants do not have to make any contributions. The I-BR1M takaful product is not offered anymore and is substituted by MySalam.

\section{d. Skim Takaful Asnaf}

The Federal Territory Islamic Religious Council had launched an asnaf takaful scheme that uses zakat funds as a source for this scheme (MAIWP Official Portal, 2020). This scheme is offered to the asnaf who receive monthly assistance from the Federal Territory Islamic Religious Council. It is intended to alleviate the burden of the asnaf who have been affected by an accident or death. Rate of the benefits offered is not clearly stated in the portal. The Asnaf Takaful Scheme was halted because the next-of-kin of the deceased did not claim the benefits due and this led to losses (Fadzli, 2018)

\section{e. 1Malaysia Micro Protection Plan}

The 1Malaysia Micro Protection Plan was launched together with the Life Insurance Association of Malaysia (LIAM), General Insurance Association of Malaysia and Takaful Association of Malaysia (MTA) in April 2011. The objective of the plan was to provide insurance protection or affordable takaful to small businesses. The rate of contribution for this plan was as low as RM10 a month with protection benefits totalling RM20000 provided for death or loss of permanent ability as well as hospital stay reimbursements of RM20 per day (LIAM, 2011).

\section{f. Prisma Etiqa Takaful}

The Takaful Prisma product is a takaful product issued by Takaful Etiqa Keluarga Berhad. This product offers protection for the takaful family with a payment as low as RM50 a month. Among the benefits provided is protection against death or loss of total and/or permanent ability (Takaful Prisma, 2021).

\section{g. FWD Kasih}

FWD Kasih is a product issued by FWD Takaful Berhad. This product provides an affordable protection plan with a payment as low as RM2.03 a month for women and RM2.54 for men. Among the benefits provided are death benefits, total and permanent loss of ability, funeral expenses, badal haji for Muslims, welfare donations for non-Muslims and death due to accidents (FWD Takaful Official Portal, 2021).

Based on these models, the source of funds for micro takaful comes from the participant, government and zakat. Funds from the government indicate a positive and encourage outcome but it is only limited to the budget allocated by the government and is 
insufficient to cover the entire poor population in Malaysia. Hence, alternative funds, such as zakat funds, should be developed and expanded so that it can provide greater benefits and assistance to a greater number of the poor. This is because zakat is one of the biggest factors that contribute towards the economic growth of Muslims.

\section{Issues and Challenges of Integrating Zakat With Micro Takaful Development}

As previously mentioned, using zakat as a source of fund for the development of micro takaful triggers few issues and challenges. The discussion on this section is generally divided into two parts. The first part is issues pertaining to Islamic law and distributing zakat funds, while the second part is related to procedures and the implementation of zakat funds as a source of funds for micro takaful (Sabri, 2019). The first part, which is related to Islamic law and distribution of zakat funds is mentioned below.

\section{The issue of owning zakat property}

According to Mikail et. al. (2017), among the Shariah issues pertaining to zakat funds as a micro takaful development fund, is that it should be divided among all the recipients of zakat (the eight categories of asnaf) or extend it to asnaf who need it, such as asnaf fakir and asnaf poor, because they are more exposed to financial risks compared to the other asnaf. This issue is connected to the word $l i$ and $f i$ in verse 60 of Surah al-Taubah (Adnan et al., 2017). It is further substantiated by Nik Abdul Ghani et. al. (2018) concerning the issue of whether tamlik zakat funds can be given to a takaful company for it to be managed or whether the zakat fund should be directly given to the zakat recipient. This issue has been debated by previous ulama concerning the definition of $J$ in verse 60 of Surah al-Taubah, which decrees zakat, whereby the definition lends the meaning of tamlik (ownership) or takhyir (choice) (alZuhaili, 2002). Allah SWT exhorted in Surah at-Taubah about the distribution and ownership of zakat funds to the eight categories of asnaf.

Meaning:

Alms are for the poor and the needy, and those employed to administer the (funds); for those whose hearts have been (recently) reconciled (to Truth); for those in bondage and in debt; in the cause of Allah; and for the wayfarer: (thus is it) ordained by Allah, and Allah is full of knowledge and wisdom (Al-Quran, at-Taubah 9:60)

According to this verse, the topic of discussion by the fuqaha' was the alphabet $J$ in

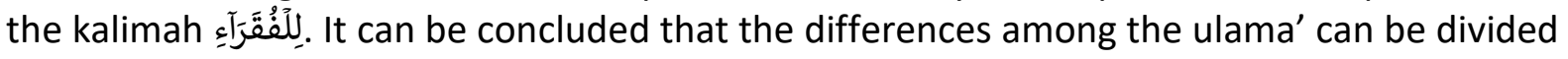
into two, as described in Table 1 below. 
Table 1. Differences in views of the Fuqaha about the Tamlik issue

\begin{tabular}{|c|c|}
\hline First View & Second View \\
\hline $\begin{array}{l}\text { 1. The Lam is a lam at-Tamlik and the } \\
\text { zakat must be shared among the eight } \\
\text { asnaf categories using the wau-tasyrik, } \\
\text { whereby the wau indicates the meaning } \\
\text { of sharing (al-Zuhaili, 2002). Hence, } \\
\text { based on this view, obligatory zakat } \\
\text { should be distributed to the eight asnaf } \\
\text { categories and it becomes their right of } \\
\text { ownership without any interference } \\
\text { such as the zakat first given to a third } \\
\text { party. }\end{array}$ & $\begin{array}{l}\text { 1. According to the Maliki sect, by using } \\
\text { the alphabet } J \text { in the kalimah }{ }^{\prime} \text { it } \\
\text { means at-Takhyir, which refers to a } \\
\text { choice of distributing the zakat to any of } \\
\text { the asnaf and it is not obligatory to } \\
\text { distribute it to all the asnaf categories. } \\
\text { The Maliki sect says that the Ruler can } \\
\text { distribute the zakat to only some of the } \\
\text { asnaf (Ibnu Rusyd n.d.). This view was } \\
\text { supported by lbnu Taimiyyah. The Maliki } \\
\text { sect ulama' said that it is sunat to } \\
\text { distribute the zakat to those who truly } \\
\text { need it compared to others. It is also } \\
\text { sunat to distribute it to the eight } \\
\text { categories of asnaf in order to avoid any } \\
\text { controversy or quarrel. This sect also } \\
\text { does not make it religiously obligatory, } \\
\text { whereby it is not obligatory to distribute } \\
\text { to all the eight categories of asnaf (al- } \\
\text { Zuhaili, 2002). }\end{array}$ \\
\hline
\end{tabular}

It can be concluded that the Maliki sect's views are consistent with the objective of zakat becoming the source of funds for micro takaful development. The views of this sect allow zakat funds to be applied to the fakr and poor through takaful institutions, which can provide better benefits and help these asnaf categories face future risks. However, is requires a strong fatwa from state Mufti(s) in Malaysia to enable the application and implementation of this view (Nik Abdul Ghani et al., 2018). This is no fatwa until today concerning whether zakat funds can be used for assisting the asnaf to own takaful policies (Sadali, 2019; al-Bakri, 2019).

Hence, the first thing that should be done is to solve the issue of fatwa by applying for a fatwa form to fatwa institutions in states that wish to implement this matter because the fatwa will determine and establish whether there is a decree that allows this matter.

\section{ii. Investing the Zakat fund issue}

Another issue is the investment of zakat funds by the takaful operator (Raffie, 2019), since normally whatever fund that is received by the risk fund will be invested to ensure that the risk savings fund grows for future distribution. According to the fatwa issued by contemporary ulama' during a conference in Dubai, zakat funds were permitted for use as investment provided the investment must only involve excess zakat funds after it has been distributed to the asnaf for their daily living expenses and the amil's (zakat collector) share can be invested (Zulkiflee et al., 2015). Following the investment issue, another problem that emerged was whether the zakat fund invested by the takaful company mixes with funds from other participants who are not in the asnaf category, in fact they are participants of the normal premium takaful policy and not the micro takaful scheme (Raffie, 2019). However, according 
to Sadali (2019), this is not an issue because usually the participants of takaful already have their own accounts managed by the takaful operator.

According to Raffie (2019), mixing the zakat fund and takaful fund, which is contributed by a non-asnaf, in one main takaful risk savings fund is one aspect of Shariah that must be evaluated by those in authority, such as the Mufti or the zakat management authority. Whereas, Sadali (2019) opined that there is no problem in combining these funds because the takaful accounts have been registered under the name of its owners and the monthly contributions have been recorded systematically. Hence, there is no problem if these funds are invested. Nevertheless, Sadali (2019) mentioned that the arising issue is related to profits from investing the zakat funds. Can the takaful company claim some of the profits from the zakat fund investment? According to Sadali (2019), profits from the zakat fund, which is a form of benefit, should be returned to the asnaf. Hence, this matter should be solved by a fatwa, which addresses matters that arise based on Islamic law.

Next is Part Two, which discusses the procedures and implementation of zakat funds as a source of micro takaful development fund. Some of the emerging issues are discussed below.

\section{Issues related to jurisdiction over zakat}

Zakat and wakaf are subject to state jurisdiction. This is based on the Malaysian Constitution Schedule IX List II, which states:

".....Zakat, Fitrah and Baitulmal or similar Islamic religious revenue, mosques or any Islamic public places of worship, creation and punishment of offences by person(s) professing the religion of Islam against precepts of that religion, except in regard to matters included in the Federal List; the constitution, organisation and procedure of Syariah courts, which shall have jurisdiction only over person(s) professing the religion of Islam and in respect only of any of the matters included in this paragraph, but shall not have jurisdiction in respect of offences except in so far as conferred by Federal law...".

Based on state Islamic religious administration enactment, zakat falls under the jurisdiction of the respective State Islamic Religious Councils (MAIN) (Badarulzaman \& Sulaiman, 2017). Hence, zakat collection and distribution are subject to individual state Islamic Religious Councils. In order to realise the suggestion of using zakat funds as micro takaful development funds, takaful cannot arbitrarily do it and it first requires permission from the relevant authorities, namely the SIRC. As for the SIRC, the suggestion to use zakat for developing micro takaful requires a fatwa from the National Muzakarah Committee (NMC) in order to implement the suggestion (Htay et al., 2015) as well as fatwa from the respective states. Hence, the fatwa application must be adduced to the fatwa institution, either at the national level, whereby the National Muzakarah Committee (NMC), which is under JAKIM, or the respective state fatwa committees chaired by the respective Mufti. In conclusion, the suggestion to use zakat funds for developing micro takaful requires a fatwa to implement it and the relevant parties need to make a fatwa application to the respective Mufti.

\section{Lack of zakat funds as a source of funds for developing micro takaful}

Lack of zakat funds is one issue that should be scrutinised before it becomes a source of funds for micro takaful. According to Sadali (2019), zakat collection fully depends on the zakat 
contributor and it is not the same year to year. This statement was also supported by al-Bakri (2019), who said that using zakat funds for developing micro takaful must be carefully scrutinised together with the sufficiency of financial resources and basic needs of the asnaf, such as food, accommodation etc., which must also be determined.

According to these two statements, zakat funds must be viewed from numerous aspects, mainly the collection and distribution of zakat. The more the distribution, the lesser the rate received by the asnaf, which is due to the lack of zakat funds. Besides that, the asnaf are not only limited to those who are fakir and poor but also involves the eight categories of asnaf that need to be managed and receive zakat funds. In a similar vein, other needs of the asnaf and the poor, such as basic needs like food, clothing and a place to live. This is because the asnaf fakr and asnaf poor not only need takaful, but they also have other needs that can be fulfilled with the help of zakat to ensure that they continue with their lives. These needs must be considered and measured carefully to arrive at a suitable figure required for micro takaful contributions that uses zakat funds.

\section{Conclusion}

Implementing zakat as one of the funds for developing micro-Takaful is a good alternative for assisting the poor, especially for owning Takaful protection for oneself and the family. Undeniably, takaful protection's importance at present is consistent with today's everincreasing developments and risks, such as the COVID-19 pandemic etc. Issues and challenges pertaining to zakat funds becoming a micro takaful development fund must be prudently solved based on Islamic decrees and implementation strategies. Therefore, when endeavouring to realise this effort, all parties need to cooperate, especially the authorities in charge of zakat and the takaful industry in order to solve emerging issues and challenges.

\section{Acknowledgment}

This research paper is sponsored by the Malaysian Ministry of Higher Education under the Fundamental Research Grant Scheme (FRGS/1/2020/SSIO/UKM/02/17) "Pembinaan Model Sumbangan Takaful Mikro Kesihatan Bagi Golongan B40 Berasaskan Dana Wakaf" (The Development of Waqf-Based Contribution Model of Health Takaful for B40 Segment)" and Geran Galakan Penyelidikan Muda (GGPM-2018-007) "Aplikasi Takaful Mikro Melalui Dana Zakat" (Application of Microtakaful Via Zakat Fund)

\section{References}

Abdul Wahid, F., \& Noordin, K. (2014). Skim Takaful Sumbangan Rendah Serta Prospek Perlaksanaan Takaful Mikro Di Malaysia. International Conference on PostGraduate Research (ICPR) 2014(December): 24-35.

Raffie, A. E. (2019). Integrasi Zakat dan Wakaf Dalam Pembangunan Takaful Mikro. Syarikat Takaful Malaysia Keluarga Berhad. Interview 7 Mei 2019.

Al-Bakri, Z. M. (2019). Integrasi Zakat dan Wakaf Dalam Pembangunan Takaful Mikro. Majlis Agama Islam Wilayah Persekutuan. Inteview 24 Mei 2019.

Al-Zuhaili, W. (2002). Fiqh dan Perundangan Islam. Jilid 11. Dewan Bahasa dan Pustaka Kuala Lumpur.

Badarulzaman, H., \& Sulaiman, S. N. (2017). Bidang Kuasa Perundangan Dalam Pentadbiran Zakat di Negeri-negeri Selatan Malaysia (December).

Bank Negara Malaysia. (2016). Microinsurance and Microtakaful : Discussion Paper. Kuala Lumpur: Bank Negara Malaysia. 
Bank Negara Malaysia. (2020). Perlindungan Tenang. Central Bank of Malaysia. https://bit.ly/3tj2BY8

Bank Negara Malaysia (BNM). (2016). Sektor Insurans dan Takaful 75-93.

Bank Negara Malaysia (BNM). (2017). Laporan Kestabilan Kewangan dan Sistem Pembayaran 75-93.

Chiew, H. L. (2017). Expanding insurance and Takaful solutions for the underserved segment. Central Bank of Malaysia (March): 1-2.

Ali, E. R. A. (2010). Panduan Asas Takaful. CERT Publications Sdn. Bhd.

Hornby, A. S. (n.d.). Oxford Advanced Learner's Dictionary. (S. Wehmeier, C. McIntosh, J. Turnbull, \& M. Ashby, Eds.), 7th Edisi . Oxford University Press.

Htay, S. N. N., Sadzali, N. S. \& Amin, H. (2015). An analysis of the viability of micro health takaful in Malaysia. Qualitative Research in Financial Markets.

Ibnu Rusyd. (n.d.). Bidayatul Mujtahid. Pustaka Azzam, hlm. Vol. 53. doi:10.1017/CBO9781107415324.004.

LIAM. (2011). Pelan Perlindungan Mikro 1 Malaysia LIAM (Life Insurance Association Of Malaysia) Annual Report 2011.

Mamdouh, A. (2016). Micro Takaful Insurance as a Tool to Guaranteeing Financing and Protecting Micro Enterprises. Journal of Business \& Financial Affairs 05(04). doi:10.4172/2167-0234.1000228

Saad, M. F. (2018). Potensi Zakat Dalam Takaful Mikro dan Kredit Mikro. Persidangan Meja Bulat. Hotel Putrajaya Bangi.

Mikail, S. A., \& Ahmad, M. A. J. (2017). Utilisation of zakāh and waqf fund in micro-takāful models in Malaysia: an exploratory study. ISRA International Journal of Islamic Finance 9 (1): 100-105. doi:10.1108/IJIF-07-2017-010

Rom, M. N. A., \& Abdul Rahman, Z. (2012). Financial protection for the poor in Malaysia: Role of zakah and micro-takaful. Journal of King Abdulaziz University, Islamic Economics 25(1): 119-140. doi:10.4197/Islec.25-1.5

Adnan, M. N. I., Hamat, Z., Yahaya, M. Z., \& Zain, M. N. (2017). Agihan Zakat Secara Mikro Kredit : Analisis Daripada Perspektif Maslahah Distribution of Zakah Fund Through Micro Credit : An Analysis from Maslahah Perspective 2(1).

Portal Rasmi FWD Takaful. (2021). Portal Rasmi FWD Takaful 2021. https://www.fwd.com.my/en/press/2020/FWD-Takaful-Offers-Micro-Takaful-Planwith-FWD-Kasih/.

Portal Rasmi MAIWP. (2020). https://www.maiwp.gov.my/i/index.php/en/jenis-skimbantuan-zakat/bantuan-takaful-asnaf.

Portal Rasmi MySalam. (2020). https://www.mysalam.com.my/b40/info.

Puad, N. A. (2017). Issues and Challenges in Developing Microtakaful in Muslim Country. Proceeding of the 4th International Conference on Management and Muamalah 2017 (ICOMM 2017), hlm. 426-433.

Sadali, H. (2019). Integrasi Zakat dan Wakaf Dalam Pembangunan Takaful Mikro. Jabatan Mufti Negeri Selangor. Interview 16 Mei 2019.

Sabri, I. I. (2019). Integrasi Zakat dan Wakaf Dalam Pembangunan Takaful Mikro. Latihan IImiah. Pusat Kajian Syariah Fakulti Pengajian Islam. Universiti Kebangsaan Malaysia 8(5): 55.

Salleh, M., \& Padzim, F, Z. (2018). The prevalence of Micro Takaful Products in the Eyes of Malaysian SMEs 5(3): 49-65.

Takaful Prisma. (2021). Portal Rasmi Takaful Prisma 2021. 
https://www.etiqa.com.my/v2/insurans-nyawa-takaful-keluarga/takaful-prisma Zulkiflee, N., Wahid, H., \& Ahmad, S. (2015). Kesedaran Terhadap Wakaf Tunai: Kajian di Besut, Terengganu. Seminar Figh Semasa (SeFis) 2015 1-11.

Zulkifli, A, M., Abd Rahman, B, H., Yassin, N., \& Ramly, J. (2012). Amalan Asas Takaful Tahap Permulaan Untuk Pengamal. IBFIM Kuala Lumpur. 